\title{
Research-Related Teaching and Learning as an Enculturation into Science
}

Ines Langemeyer

Does pedagogy need models? Although the question may cause astonishment, models are an integral part of scientific and professional practice. They are used in architecture to visualize building site plans, in economics for the reconstruction (and if possible the forecasting) of complex economic developments, and in physics to explain certain laws, especially where observation is no longer able to accomplish anything (at an atomic level, for example). But what is the purpose of models in teaching-learning research? Is their purpose to illustrate, reconstruct or explain teaching and learning?

The model for undergraduate research and inquiry developed by Healey and Jenkins (2009) has become well known. It depicts a polarization along two orthogonal axes (see figures in Mieg or Reiber, in this volume) between the active and receptive role of students on the one hand, and between the research process and the results of research as teaching content on the other, making it possible to identify four different teaching practices.

What is the purpose of this model? Does it illustrate real practice? Probably not, because it abstracts the many concrete phenomena of the multifaceted teaching-learning process. Not taken into consideration, for example, are which learning challenges are involved in research-driven activity - whether a fresh topic will be introduced or whether students will transfer and/or reinforce what they already know by applying it in a research project (or a portion thereof). In general, the intentions of the educators remain rather unclear. It is not specified, for example, whether their goal consists of developing students' capacity to think, or to help them to become more independent by engaging in research activities.

I. Langemeyer, Prof. Dr. $(\bowtie)$

Karlsruher Institut für Technologie, Institut für Berufspädagogik und Allgemeine Pädagogik/

House of Competence, Professur für Lehr-Lernforschung, Karlsruhe, Germany

e-mail: ines.langemeyer@kit.edu

H. A. Mieg (ed.), Inquiry-Based Learning - Undergraduate Research, https://doi.org/10.1007/978-3-030-14223-0_7 


\subsection{Empirically Founded Modeling of Research-Related Teaching and Learning in Higher Education}

In three online surveys conducted among educators (at the Karlsruhe Institute of Technology in 2013 and 2016, and at the University of Tübingen in 2014), investigated research-driven teaching, hot on the heels, as it were, of the model of Healey and Jenkins (Langemeyer and Rohrdantz-Herrmann 2014). Explorative factor analyses have shown that, from a subjective perspective, a distinction can actually be made between two approaches to research-related teaching for all data sets: In the first approach, teaching is process-oriented and students conduct experiments, projects, research, etc. largely independently. In the second approach, the focus is on the transfer of knowledge, in which students give talks or presentations, demonstrate their experiments, but also search independently (e.g. information, literature). We could thereby consider both the vertical axis of the Healey-Jenkins model, and also the horizontal axis, to have been confirmed. Nevertheless, the empirical findings can also be interpreted differently.

The following way of modeling practice places long-term and short-term objectives in the foreground as structuring features. Short-term goals can be modified as the situation demands while maintaining the long-term goal. Each short-term goal specifies the longterm goal. Thus this analytic view also takes into consideration the subjective premises of behavior and does not necessarily regard these forms of teaching as opposites. The analysis of the 2016 survey conducted among educators confirms that this would be misleading (Langemeyer 2017). It would be more correct to arrange the forms of teaching in parallel, since educators observe students and then decide whether to first organize learning more as understanding or more as independent development. It is possible to switch between the two modes, however. The choice is made by assessing whether it makes more sense to teach students the basics, to show, explain to and discuss research with them, or whether to enable them to do independent research. Both modes can be realized in all phases of research, roughly stated in (1) problem identification (understanding or finding a research question), (2) acquiring an understanding of or conducting a study, in which theory and empiricism or different theories are related to one another and (3) when reviewing, providing evidence for, and forming a judgment about the findings of the investigation (see Fig. 7.1). Realistically, educators will not strictly choose one mode or the other, but switch back and forth between them so that students know why they can research something and how they can draw a conclusion.

In both cases of the research-related acquisition of experience, the teacher tries to work towards an enculturation process in their long-term goal: They attempt to teach students the distinction in scientific thinking and to certain scientific ethos and the rigor of a particular discipline. At this point, it should be stressed that the short-term goals of the instructor can - and indeed must - vary within the long-term goal of enculturation. These short-term goals are specified under various, alterable premises, for example study phases or course requirements. The structuring of teaching behavior does not always correlate with the implementation of a didactic plan on a one-to-one basis; under no circumstances 


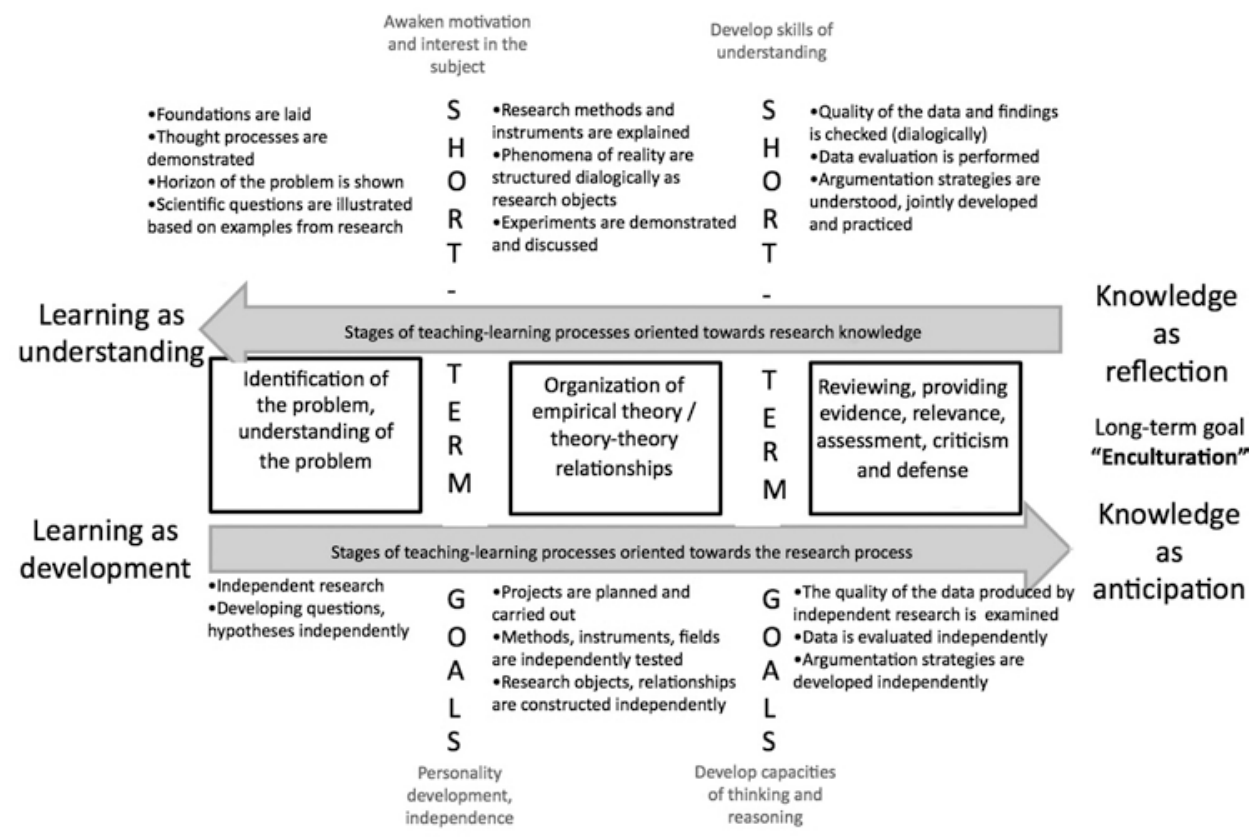

Fig. 7.1 Research-related academic studies as an enculturation process. (Source: author's representation)

is it a mere either/or decision made between "receptive" versus "active" (in the case of student roles). This is because it is not just development, but also the processes of understanding that requires a mode of learning activity. The essential structuring of teachinglearning processes is at the relationship level and must be understood psychodynamically.

\subsection{Enculturation as a Guiding Principle}

As a concept, enculturation can be developed theoretically with the help of a number of sources. In the following, I will first draw on gestalt psychology and the reception thereof by the philosopher Michael Polanyi, secondly on the work of the biologist and science theorist Ludwik Fleck, and thirdly on the work of the psychologist Lev S. Vygotsky. Although these sources have many intersections, the authors listed here are not directly connected in a historical context.

Enculturation (independent of the specific scientific orientation) is becoming important because science exists in the form of epistemic cultures (Knorr Cetina and Reichmann 2015). Research processes and the teaching-learning process based thereon are partly similar to professionalization processes. Both (at least partially) open themselves up to the problematic, the unforeseeable, to what is not yet known, or to the coincidental (Langemeyer 
and Rohrdantz-Herrmann 2015), which is intended to prompt questioning and researchoriented behavior in learners (Huber 2009, p. 9).

Learning how to pursue scholarship is a long, never-ending self-teaching process that transcends a well-defined and didactically predictable teaching-learning process. For this reason, research-related instruction aims to show students the possibilities of thinking and acting with which they can continue to work in an area autonomously and independently, since it is only in this way that subjectively meaningful connections arise between individual learning processes.

Thus, from the point of view of the educators, the research-related instruction is less about optimal preparation for exams or about forms of individualized instruction. As was noted in the comment fields of the survey, research-related teaching is regarded as important because it "helps to introduce students to reflection on the subject's research questions" and because it thus promotes "analytical skills and transfer skills." Nevertheless, the notion that such skills could be formed directly through teaching is viewed critically. It is sometimes even negated: "Skills such as analytic thinking, the transfer of ideas as well as a deeper understanding of a subject, etc. unto themselves have nothing to do with the content of teaching." One participant interpreted the "educator's role in implementing resultsoriented study projects" via the "need [to support the] open research process in terms of content and group dynamics until a presentable result suitable for the general public without direct intervention (pursuant to the motto: prepare and point in the right direction, then stay calm and wait, but also steer and push in the right place)". All quotes in the comments fields have been taken from the survey conducted among educators at the University of Tübingen in 2014.

In addition to the independent acquisition of experience, students should also familiarize themselves with a state of research by presenting research findings and learn to grasp differences in the development of various theories by demonstrating possibilities of thinking. By showing and demonstrating certain solutions to problems, they should be inspired by one or another methodological approach and actively engage in research questions by discussing together. The long-term goal of enculturation thus essentially overarches the respective didactic preparation of the material in courses. It does not merge with it, however.

Research-related teaching always includes a number of short-term goals, some of which are pursued in parallel at different levels. As such, a guiding idea is to broaden the students' thinking, so that the latter can go beyond what is known and understood and think independently. This long-term goal is neither the sum of the short-term goals nor compatible with the concept of a modularized acquisition of competences. 


\subsection{Theoretical Foundations of the Concept of Enculturation}

These assumptions are further substantiated below by drawing on Michael Polanyi, Ludwik Fleck and Lev Vygotsky. All three approaches, which were developed in the first half of the twentieth century, share a specific understanding of thought, knowledge and science (for details, see Langemeyer 2015). Gestalt psychology, the holistic core idea of which states that cognitive percepts are global wholes that have more significance than the sum of their parts, had a significant impact on this. In the case of Polanyi, this idea is applied directly to the process of thought; Fleck links thought to the collective process of recognizing and the emergence (not just the discovery!) of facts. Vygotsky adopts this basic assumption in his methodological work on the relationship between general and individual science.

Even before Polanyi, gestalt psychologists explain the ability to recognize a percept through the figure-ground organization: Elements arrange themselves in the process of perception as a figure or as a percept when they come together in the foreground. Analogously, every realization can be understood as a holistic perception of elements in which there is a movement from the details to the whole - to the gestalt figure. Recognizing a face, for example, means recognizing its elements (especially the eyes, nose and mouth) as a whole. One is not focused on the elements themselves, but instead, one looks through them to see the entire face. Polanyi (1959) uses the term subsidiary for that, which is consciously in the background, thus temporary consciousness: Being aware of something subsidiary means that we are not aware of unto itself, but are aware of it as a clue or instrument that points beyond itself (cf. Neuweg 1999, p. 189).

Thinking therefore always completes a movement from a proximal to a distal term, e.g. from the eyes, nose, mouth, etc. to the face (cf. ibid; cf. Polanyi 1966). What is surprising about intellectual activity is that the integration between the proximal and the distal term is experienced as both active and passive. "On the one hand, [the integration is] induced by the subject, while on the other hand, it happens to the subject" (Neuweg 1999, p. 206, translated), as can be seen in the example of a scientific discovery: "We make it, and yet it surprises us" (ibid.). This is what constitutes the sometimes elusive nature of learning and research processes, but which also gives them the power to elicit enthusiasm and motivation in those who experience them.

Therefore, let us transfer Polanyis' fundamental ideas to learning experiences in scholarship! Scholarly communities have the power to organize a specific way of thinking and perceiving. If such a community (further) develops theories, it thereby actively clears away specific orders of perception in order to consciously restore them in a changed relationship. This new relationship is guided by a certain new theoretical organization of seeing and thinking. What people in day to day life often do not realize is that, since everyday theories also structure perceptions, students must first learn to reflect on the premises of their thinking. Every scientifically driven reorganization of thought is based on the experiences of previous generations and scholarly communities, however. The laboriousness of 
the work of questioning and revising forms of perception is illustrated by Vygotsy's commentary on the realizations about the "earth rotating around the sun" and the "vision of ants":

How much critical work on our perceptions and, thus, on the concepts linked with them, how much direct study of these concepts - visibility, invisibility, apparent movement -, how much creation of new concepts, of new links between concepts, how much modification of the very concepts of vision, light, movement etc. was needed to establish these facts! (Vygotsky 1997, p. 251)

Fleck also shows that the questioning concepts and forms of perception are not just a learning process of an individual person. Scientific experiences are therefore more than just personal experiences. They must be situated within the context of historical-social experiences. Fleck therefore speaks of thought collectives. Communities alone would muster up the strength to reshape the disorder of all real correlations in a system of knowledge: "Between the subject and the object there exists a third thing, the community. It is creative like the subject, refractory like the object, and dogmatic like an elemental power" (Fleck 1960/2011, p. 470, translated).

Historically, the cultural framework in which facts are seen and interpreted arises in relation to the common way of life and forms the background for the way to ask and to research. That framework determines the "moodiness of the researcher," which, in turn, decides "whether he perceives the new percept as a symbolic glaring vision, or as a feeble aviso of resistance, which slows the unbounded, almost arbitrary choice from among the alternating images," for example (Fleck 1935/2011, p. 232, translated). This is why researchers and learners in science face the challenge of breaking with some culturally learned everyday forms of thinking in order to be able to understand the experiences of previous generations and scientific communities.

In addition, Fleck observed what happens when people wish to engage in science without the enculturation process, and without being familiar with the specific thinking styles and forms of perception. The insight into this need came to him in several bacteriological laboratories. One experience in particular was crucial to him: When he (1945/2011, p. 492 et seq.; 1948/2011, p. 538 et seq.) arrived at Buchenwald concentration camp as a prisoner in 1943, he worked there as a specialist in the typhus vaccine. There was already a working group there, also made up of prisoners; however, they had no expertise in this field. Thus for more than two years, Fleck had the opportunity "to observe the scientific work of a collective comprised entirely of laymen" (1935/1983, p. 135 et seq., translated). The group believed that it had found typhus pathogens, which Fleck was in fact able to identify as granules of stain from white blood cells from the laboratory animals being used for the research. The group was correspondingly far from developing a viable vaccine for the Nazis, which Fleck did not reveal, however. They had simply learned about the appearance of the pathogen from the scientific literature. The reason they were convinced of their own discovery can be explained as mutual reinforcement, the buildup of expectation of seeing 
specific effects, the desire for recognition, competitiveness, and the desire to satisfy the group leader (ibid.). In epistemological terms, Fleck comments on this (ibid., translated): "The elements of the mood were, in principle, identical to those normally encountered. I observed a situation of this kind - the birth of the discovery." Against this background, he concludes that "the social mechanism that gives rise to an error [is] the same as the mechanism that gives rise to true knowledge" (Fleck 1946/1983, p. 140, translated).

By supporting the notion of enculturation with these theses, we can identify several key aspects of learning processes in a research-oriented course of study. It becomes obvious that a scholarly course of study in a field means more than knowledge of the technical literature and access to research equipment and methods. In particular, the absolutely necessary process of independently learning science and the requirements of science is not possible without the prerequisite of having been part of a thought collective. It is only by participating in a scientific community and its special style of thinking that students can meaningfully and adequately deal with the opportunities for thought and action offered hereby and learn to recognize errors. Important experiences arise during the enculturation process within the frame of reference of a discipline, in that research questions or "facts" are theoretically interpreted and questioned. As with Polanyi, empirical experiences and theoretical considerations organize themselves in a certain way "in the background" as a result of participation in a collective style of thinking. This creates a "system of knowledge" of how something becomes a subject of research, what subject matter may or must be made the object of empirical study, and what cannot be considered as such.

This cultural-historical view of the history of science can be supplemented by further insights by Vygotsky. He examines how the acquisition of scientific concepts restructures intellectual activity. For him, every concept is a theory (or form of perception) that performs a different task for scientific thinking. In his view, ideas do not express themselves in language, but are rather born and completed within it. Thus, for Vygotsky, a purely empirical science without philosophical work on one's own concepts is not possible. Concepts have always had a problematic relationship with empirical facts. This is because, "if concepts, as tools, were set aside for the facts of experience in advance, all of science would be superfluous" (Vygotsky, 1927/2003, p. 93, translated; cf. 1997, p. 325). In general and special science, philosophical work differs only in terms of its function within concrete cognitive activity in a scientific field. Thus, he draws a comparison between scientific work, which is done within the limits of a single study (or special science), and the "function of a funnel," where the object being examined "condenses theories into hypotheses" (Vygotsky, 1927/2003, p. 97). However this same function is likewise fulfilled by "general science with the same procedures and the same goals for multiple special sciences" (ibid.).

This results in a reciprocal, dialectical relationship between two types of experience: One focuses on the aspect of how a research subject has been theoretically conceptualized and changed in the research process. The other proceeds indirectly along the same process by reflecting on the theoretical concepts. It examines how perceptions were initially 
organized, how a certain theoretical classification was made, and how it can be systematically evaluated on the basis of individual empirical observations.

\subsection{What Are the Implications?}

As has been shown, the concept of enculturation can be used to describe the process of inquiry-based learning as the appropriation of scientific practice in the mode of selfeducation, but also of participation. Moreover, research-related teaching as a specification of this process is made clear by short-term goals. This more complex understanding goes far beyond the need to systematize manifestations of the teaching-learning process that have only been considered superficially. It leads to the level where interactions occur between the actions of educators and the actions of students; these interactions repeatedly undergo reflection within the research-oriented course of study. The central issue for educators, which is currently the most pressing issue for students as well, can be decided through the orientation towards the long-term goal of enculturation. Without this long view, it would be necessary either to proclaim the option of inquiry-based learning impossible, or to curtail the research itself, for example by limiting it to simply repeating experiments that have already been performed. However, this would simply sweep under the carpet the challenges of research questions that are as yet unresolved, and the difficulties of conducting, reviewing and defending one's own steps in research. If the objectives of higher education policy, such as anchoring inquiry-based learning in modularized degree programs, are to be achieved, it seems necessary to obtain deeper insight into the dynamic of the teaching-learning process and to not be guided by supposed opposites that are, in fact, not oppositional.

\section{References}

Fleck, L. (1983). Erfahrung und Tatsache. Gesammelte Aufsätze. Frankfurt/M.: Suhrkamp.

Fleck, L. (1935/1979). Genesis and development of a scientific fact. Chicago: The University of Chicago Press. (Original work in German, published 1935)

Fleck, L. (2011). Denkstile und Tatsachen: gesammelte Schriften und Zeugnisse. (hrsg. v. Werner, S./ Zittel, C./Stahnisch, F.). Frankfurt/M.: Suhrkamp.

Healey, M./Jenkins, A. (2009). Developing undergraduate research and inquiry. York: Higher Education Academy.

Huber, L. (2009). Warum forschendes Lernen nötig und möglich ist. In L. Huber/J. Hellmer/ F. Schneider (Hrsg.), Forschendes Lernen im Studium (S. 9-35). Bielefeld: UniversitätsverlagWebler.

Knorr Cetina, K./Reichmann, W. (2015). Professional Epistemic Cultures. In I. Langemeyer, M. Fischer/M. Pfadenhauer (Hrsg.), Epistemic and Learning Cultures - Wohin sich Universitäten entwickeln (S. 18-33). Weinheim: Beltz Juventa.

Langemeyer, I. (2015). Das Wissen der Achtsamkeit. Kooperative Kompetenz in komplexen Arbeitsprozessen. Münster: Waxmann. 
Langemeyer, I. (2017). Forschungsorientiert Lehren und Studieren. Empirische Untersuchungen zu Lehr-Lernformen, Gründen, Erwartungen und Einstellungen am KIT. Karlsruhe: KIT.

Langemeyer, I./Rohrdantz-Herrmann, I. (2014). Forschungsorientiertes Lehren. Eine Bestandsaufnahme am KIT. A + B Forschungsberichte. Retrieved 1 July 2015 from http:// www.ibap.kit.edu/berufspaedagogik/download/AB_Forschungsbericht_Lehrendenbefragung_ 20140723.pdf

Langemeyer, I./Rohrdantz-Herrmann, I. (2015). Wozu braucht eine Universität LehrLernforschung? - lädoyer für eine entwickelnde Forschung. In I. Langemeyer, M. Fischer/ M. Pfadenhauer (Hrsg.), Epistemic and Learning Cultures - Wohin sich Universitäten entwickeln (S. 211-227). Weinheim: Beltz Juventa.

Neuweg, G. H. (1999). Könnerschaft und implizites Wissen. Zur lehr- und lerntheoretischen Bedeutung der Erkenntnis- und Wissenstheorie Michael Polanyis. Münster: Waxmann.

Polanyi, M. (1959). The study of man. Chicago: The University of Schicago Press.

Polanyi, M. (1966). The tacit dimension. Chicago: The University of Schicago Press.

Vygotsky, L. S. (1997). The historical meaning of the crisis in psychology: A methodological investigation. In Rieber, R. W., \& Wollock, J. (eds.), The collected works of LS Vygotsky (pp. 233343). Springer US. (Russion original in 1927)

Open Access This chapter is licensed under the terms of the Creative Commons AttributionNonCommercial-NoDerivatives 4.0 International License (http://creativecommons.org/licenses/bync-nd/4.0/), which permits any noncommercial use, sharing, distribution and reproduction in any medium or format, as long as you give appropriate credit to the original author(s) and the source, provide a link to the Creative Commons licence and indicate if you modified the licensed material. You do not have permission under this license to share adapted material derived from this chapter or parts of it.

The images or other third party material in this chapter are included in the chapter's Creative Commons licence, unless indicated otherwise in a credit line to the material. If material is not included in the chapter's Creative Commons licence and your intended use is not permitted by statutory regulation or exceeds the permitted use, you will need to obtain permission directly from the copyright holder.

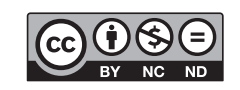

